\title{
Jordanian Wedding Invitation Genre During the Covid-19 Pandemic
}

\author{
Ahmad I. Tawalbeh \\ Department of English Language and Literature, Irbid National University, Irbid, Jordan
}

\begin{abstract}
This study examines the generic components of Arabic wedding invitation cards issued during the Covid-19 period in Jordanian society. It aims to find out the role played by the Covid-19 pandemic in shaping the rhetorical structure (moves and steps) of these cards. The sample consists of 100 electronic wedding cards which were analyzed using top-down (genre analysis approach) and bottom-up processing. The analysis shows that there are nine component moves realized by certain steps, shaping the invitation genre. It is found that this genre is subject to change which essentially affects its common main communicative purpose, viz. to invite people to celebrate the wedding in a place. It is hoped that the results of this study may confirm previous literature about the effects of the surrounding context on shaping a genre, help familiarize those interested in knowing about this Arabic genre and offer insights for those interested in conducting cross-cultural contrast.
\end{abstract}

Index Terms - Arabic wedding invitation, Covid-19, genre analysis, moves, rhetorical structure

\section{INTRODUCTION}

The wedding invitation card can be defined as a social practice in which inviters kindly inform and request the presence of invitees. This definition includes two important communicative purposes which would realize the invitation genre. The first is to inform invitees and potentially announce to public that a wedding will be held. The second is to gather invitees in a specific place to celebrate the marriage (Johns, 1997). This matches with the concept of invitation as a social event wherein people are kindly requested to attend a gathering (Al-Ali, 2006). Therefore, this type of genre can go under the umbrella of what Miller (1984) calls 'homely discourse', as it is an instance of everyday language like birth and obituary announcements.

In addition to the communicative purpose, wedding invitation cards may include conventionalized content and form that can help the audience easily identify this type of genre (Johns, 1997). The elements of the invitation, according to Johns, are represented in a conventional phrasal form appearing in separate lines. The content of such cards may present the name of the genre, the name of the bride and groom and the place and time of the wedding.

Jordanian wedding invitation cards have been studied by a number of researchers (Al-Ali, 2006; Momani and AlRefaei, 2010; Sawalmeh, 2015, 2018). They analyzed the generic components of these cards giving special attention to the role of socio-cultural factors in shaping this genre (see section II). However, there has not been any published research, to the best of the researcher's knowledge, which dealt with the rhetorical structure of the Jordanian written wedding invitations issued during the Covid-19 pandemic. As the above researchers found that the socio-cultural aspects are reflected in this genre, it is possible to expect that the new emerging context of Covid-19 has influenced this genre or the articulation of its communicative purpose. It would be interesting to study this potential influence and find out how this genre has changed, if it does, as genres may develop over time (Swales and Najjar, 1987).

The first wave of Covid-19 in Jordan began in a city in the north of Jordan in March 2020. The initial cause of the virus spread was due to a wedding ceremony. This urged the government to apply strict civic restrictions and ban any gathering that increases the spread of the virus. All places, such as halls and hotels, where wedding celebrations are usually held, have been closed since the beginning of the pandemic. Only the bride and the groom and a few members of their families can take part in the wedding ceremony. These changes affecting all aspects of the wedding ceremony may be significantly reflected in the wedding cards. Therefore, this research is important as it aims to find out if these changes have affected the generic components of the invitation cards.

This study is also important for those interested in becoming familiar with such common social practice in Jordan as the wedding, occurring during the Covid-19 pandemic. It would familiarize them with the generic components and structure of the wedding invitation cards issued during this pandemic and thus may help them understand the nature of these cards in Arabic. This would teach student writers an example of how "genres are socially real" (Johns, 1997). Therefore, the invitation genre would introduce students to the concept of genre in general and may help them in their study of some other types of genres like the academic.

The components of the invitation cards will be explored based on the communicative purpose identified therein. Biber (1988), Swales (1990) and Bhatia (2013) maintain that the communicative purpose is important to identify a genre. Following Swales, this research uses the terms 'moves' and 'steps' to refer to the components of the invitation genre. A 'move', according to Tawalbeh $(2019$, p. 26), is "part of a text which consists of categories having specific purposes and is realised by some linguistic choices". This part of text carries a communicative function and can be 
divided into smaller elements called 'steps'.

Aim and Objectives of the Study

This study aims at investigating a potential change in the Jordanian wedding invitation genre issued during the Covid-19 pandemic. This is to be achieved by realizing the following objectives: 1 . analyzing the rhetorical structure (moves and steps) of the invitation genre; 2. identifying the linguistic exponents realizing these moves and steps; 3 . identifying the non-linguistic features; and 4 . describing the moves sequence.

\section{LITERATURE REVIEW}

Genre analysis, as conducted by Swales $(1990,2004)$ and Bhatia (2013), relies on the communicative purpose to identify a genre and on the minor functions, which participate in shaping the whole communicative purpose and to identify the component moves and steps of that genre. Swales has offered a significant contribution to the generic analysis of academic texts as he analyzed the introduction section of research articles using move/step analysis approach. Similarly, Bhatia used this approach in his analysis of research articles abstracts. Swales and Bhatia's work represents remarkable examples of using move analysis approach in academic discourse and offers the possibility of extending the applicability of this approach in the genre analysis domain. For example, some researchers have extended this approach to other sections of research articles, such as the results section (Brett, 1994), the discussion section (Holmes, 1997) and the methodology (Tawalbeh, 2019). Some other researchers have also applied move analysis to other non-academic genres, such as the wedding invitation genre (Al-Ali, 2006; Momani and Al-Refaei, 2010; Sharif and Yarmohammadi, 2013; Sawalmeh, 2015).

Sharif and Yarmohammadi (2013) used Swales' genre analysis model to analyze 70 Persian wedding invitations. They found that these invitations are realized by seven moves, namely "Opening", "Identifying the bride and the groom by first name", "Announcing the couple's marriage", "Requesting the participation of the recipients", "Identifying the bride and the groom by last name", "Situating the wedding ceremony" and "Other optional components". Sharif and Yarmohammadi reported that the organization of this genre is influenced by the socio-cultural conventions of that society and ascribed the most influential role to religion.

In the Jordanian context, Al-Ali (2006) analyzed 200 Arabic wedding invitations to investigate the role of sociocultural context in shaping this genre. Similar to Sharif and Yarmohammadi, Al-Ali reported that religious affiliations and masculine authority affect the construction of the invitations and the lexical items employed therein. The moves which construct this genre in Al-Ali's study are similar to those in Sharif and Yarmohammadi's, namely: "1. Opening 2. Heading 3. Identifying the inviters 4 . Requesting the presence of others 5 . Identifying the bride and groom 6 . Situating the wedding ceremony 7. Closing 8. Other optional components" (Al-Ali 2006, p. 699). Both Al-Ali and Sharif and Yarmohammadi's studies show that this invitation genre is not isolated from the context in which it occurs and thus they motivate studying this genre within the new context of Covid-19.

The moves mentioned above also appeared in Momani and Al-Refaei (2010) and Sawalmeh's (2015) studies of Jordanian wedding invitations. The differences between these two studies and Al-Ali's are only in using different labels for naming some of the moves which carry the same function. Move 2, 'Heading', move 6, 'Situating the wedding ceremony' and move 8, 'Other optional components' in Al-Ali's study are named as 'identifying the celebrating families', 'ceremony arrangements' and 'Notification', respectively, in Momani and Al-Refaei (2010) and Sawalmeh's (2015) study. The similarities found in all the studies above raise a question whether the wedding invitations issued during Covid-19 still carry the same communicative purpose and functions, or not. Therefore, this study attempts to fill the lacuna in literature by investigating the rhetorical structure of the Jordanian wedding invitations which have been issued during the Covid-19 pandemic.

\section{THEORETICAL FRAMEWORK}

\section{A. Socio-cultural Aspect of the Jordanian Society}

Understanding the socio-cultural context in which Jordanian wedding invitations occur would help gain an understanding of the rhetorical features of the invitation genre in question. This is because: 1. the selection of rhetorical features relies on the culture (Bhatia, 2014); 2. considering the native context of wedding invitations, in terms of the social conventions that give rise to occasions like weddings, would help understand the characteristics of such a genre (Momani and Al-Refaei, 2010); and 3. a genre can be influenced and defined by the social context in which it occurs (Kress and Knapp, 1992). Therefore, this section sheds some light on wedding ceremonies in Jordanian society.

Wedding ceremonies in Jordan usually take place in two phases. The first is engagement (the khutbah) wherein requesting the hand of the bride occurs. This event is run by Jaha which is a group of the groom's relatives and friends that head to the bride's house where they are received by a similar group. If the proposal is accepted, the groom and the bride sign ' aqid qaran (marriage contract) after which the groom places a ring on the bride's finger. This is usually followed by a small party in the bride's house or in a hall. The second phase is the wedding ceremony zafaaf that is arranged by the groom, the bride and their families. The arrangements include deciding on the time and place of the wedding, and who the invitees are. The groom and bride visit an invitation cards shop to select the design of the cards which are then sent to their relatives, friends and neighbors. Wedding ceremonies in Jordan may begin with one- or 
two-night's celebrations where men and women sing, dance and stamp their feet separately till midnight. Guests are sometimes invited to a wedding feast served by the groom's family who slaughters goats and sheep and cook the traditional dish 'mansaf'. After that, invitees gather in a wedding hall or a hotel to celebrate the wedding occasion. Nowadays, due to the Covid-19 pandemic, weddings halls have been closed and any gathering which includes more than 20 people has been forbidden.

\section{B. Genre Analysis}

The concept of genre analysis is essential to this research as it is used to interpret and identify the organizational structure of the wedding invitations. The genre analysis conducted in this research follows the approach of English for specific purposes (ESP). Bruce (2008) states that the ESP framework examines the organizational features of a text and their linguistic exponents. The seminal work in genre analysis within this framework was initiated by Swales (1981), as mentioned above in section II. Swales (1990, p.48) states that genre

comprises a class of communicative events, the members of which share some set of communicative purposes. These purposes are recognized by the expert members of the parent discourse community, and thereby constitute the rationale for the genre. This rationale shapes the schematic structure of the discourse.

Swales shows the importance of the communicative purpose in identifying the discourse units (moves and steps) of a genre, which in their turn shape the schematic structure of discourse. This structure, for Swales, is a result of conventions shared by a specific discourse community. The wedding invitations tackled in this study communicate the social event of invitation and cannot be composed without considering the social context including the surrounding circumstances wherein these invitations occur. The invitation genre can be considered a social genre which is, according to Bruce (2008, p.8) "socially recognized constructs according to which whole texts are classified in terms of their overall social purpose'. Bhatia (2002) also confirms the idea that genres are conventionalized constructs used to achieve the purpose of a specific discourse community. For him, genre analysis means

investigating instances of conventionalised or institutionalised textual artefacts in the context of specific institutional and disciplinary practices, procedures and cultures in order to understand how members of specific discourse communities construct, interpret and use these genres to achieve their community goals and why they write them the way they do. (Bhatia 2002, p. 6)

\section{DATA AND PROCEDURES}

The data for this study consists of 100 Jordanian written wedding invitation cards issued during the Covid-19 pandemic, from the end of April 2020 till March 2021. These cards were collected electronically using social media, Facebook and WhatsApp. The moves and steps in these cards were identified and some examples with their translations were given to show how these moves and steps are realized. The lexical items that exemplify a move or a step are put in italics.

\section{A. Procedures of Analysis}

This study used both top-down and bottom-up processing for a deep and comprehensive analysis of the data (see Tawalbeh 2019, for the usefulness of employing both top-down and bottom-up). The invitation cards were analyzed in terms of moves and steps using Swales' (1990) move analysis approach. This approach works as a top-down processing method and relies on breaking the higher elements of the text into smaller ones. It also requires understanding the communicative purpose of the whole text and the particular function of text segments to help identify the moves and steps. To do so, it is helpful to build some expectations about what the text may contain. Therefore, Sawalmeh's (2015) outline (see below) was used as an analytical framework in this study. His outline contains detailed elements of Jordanian wedding invitation cards and covers those found in the previous studies conducted on Jordanian wedding invitations by Al-Ali (2006) and Momani and Refai (2010). His outline would be helpful to show the constituting elements shaping this genre before Covid-19. It helps the researcher to compare it with the present sample and find out whether this genre has changed or not.

\section{B. Analytical Framework}

The framework used in analyzing the current data is Sawalmeh's (2015). He conducted his analysis on 500 Jordanian wedding invitations and found the following constituting elements:

1. Opening

2. Identifying the celebrating families

3. Identifying the inviters of the wedding

4. Requesting the presence of the guests

5. Identifying the bride and groom

6. Stating wedding ceremony arrangements

7. Deferential ending

8. Notifications

By applying top-down processing in a preliminary analysis, the researcher assigned a move from Sawalmeh's outline 
to the segments of the current text. These segments were identified according to the communicative function they carry. It was found that a few elements from the present sample do not have their equivalent in Sawalmeh's outline; therefore, the researcher conducted a bottom-up analysis. The use of bottom-up processing helped the researcher conduct finegrained analysis and discover new features that are not part of Sawalmeh's predefined components. The researcher used this processing to follow organized steps to form a detailed outline of the data. This process began with analyzing the linguistic items at the bottom level. This microstructure analysis includes investigating the lexical items, types of phrases and tenses employed to realize a step. In a higher level, a group of steps were then classified under a move type according to the function they perform. The result is adding new elements to Sawalmeh's outline and composing an outline for the moves and their steps in the top level of bottom-up processing, as seen in the results section.

The quantitative aspect of this study includes recording the occurrence frequency of moves to help show the status of each move. This aspect would help indicate which moves can be considered obligatory to realize the invitation genre. Kanoksilapatham (2005) demonstrates that a move can be considered either conventional or optional according to its frequency. For Kanoksilapatham, if a move occurs in more than $60 \%$ of the data, it is considered conventional, while an occurrence that is less than $60 \%$ would indicate that a move is optional. This cut-off percent would help the researcher build assumptions about the status of the moves realizing the invitation genre.

\section{RESUlTS AND DisCUSSION}

The analysis shows that the genre of wedding invitation cards has been influenced by the Covid-19 pandemic. Although the moves and steps found in the present sample are similar to those in Sawalmeh's (2015) outline, a few new moves and steps have appeared and apparently changed the whole communicative purpose of this genre. The moves with their constituent steps are presented in table 1 below wherein the new elements are highlighted. The differences between the components found in the present data and those in Sawalmeh's are discussed below, as they reveal the changes affecting this genre.

TABLE 1

THE MOVES AND STEPS OF THE WEDDING CARDS

\begin{tabular}{|l|l|}
\hline Moves & steps \\
\hline 1. Heading & \\
\hline 2. Opening & $\begin{array}{l}\text { 1. Qur'anic verse } \\
\text { 2. prophetic invocations } \\
\text { 3. poetic verse }\end{array}$ \\
\hline 3. Identifying the celebrating families & \\
\hline 4. Identifying the inviters of the wedding & \\
\hline 5. Announcing marriage and requesting distant participation & $\begin{array}{l}\text { 1. invitation for distant participation } \\
\text { 2. seeking invitees' invocations }\end{array}$ \\
& $\begin{array}{l}\text { 3. announcing marriage } \\
\text { 4. justifying distant participation } \\
5 . \text { identifying the channel of participation }\end{array}$ \\
\hline 6. Identifying the bride and the groom & \\
\hline 7. Stating wedding ceremony arrangements & $\begin{array}{l}\text { 1. day and date of the wedding } \\
\text { 2. ceremony arrangements }\end{array}$ \\
\hline 8. Deferential ending & 1. making wishes and invocations \\
\hline 9. Notifications & 1. name of publishing company or the designer \\
\hline
\end{tabular}

The following is a sample of a wedding card from my data. It is followed by another figure which gives the English translation and transliteration of this card and shows the constituting moves that appear in this card. 


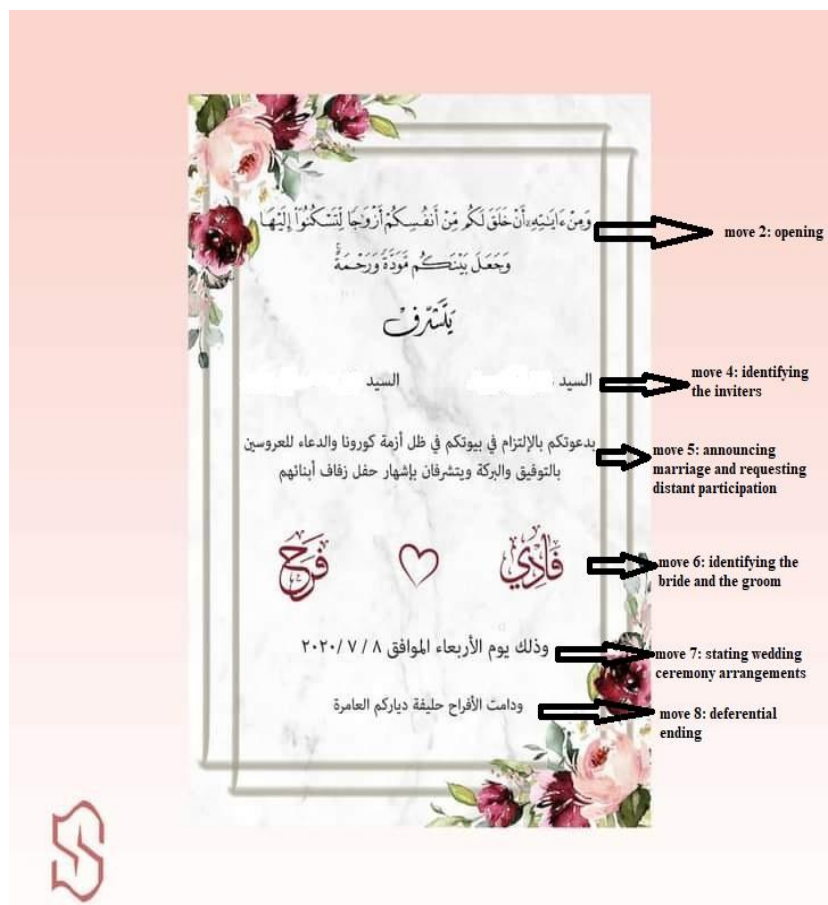

Figure 1. A sample of a Jordanian wedding card

wamin Pa:ya:tihi Pan khalaqa lakum min Panfusikum Pazwa:jan litaskunu Pilayha: wajacala baynakum mawadatan warahmah (move 2: opening)

"And among His Signs is this, that he created for you mates from among yourselves, that ye may dwell in tranquility with them. And He has put love and mercy between your (hearts)"

$$
\text { yatasharaf }
$$

is honored

Passayed X

Passayed Y

Mr. name of the bride's guardian (move 4: identifying the inviters) Mr. name of the groom's guardian

bidac ${ }^{c}$ atikum bilPiltiza:mi fi buyu:tikum fi THili Pazmati ku:ru:na: waduca:?i lilcaru:sayn bitawfi:qi walbarakati wayatasharafa:n bi?ishha:ri hafli zafa:fi Pabna:Pihim (move 5: announcing marriage and requesting distant participation)

to invite you to abide in your homes in the light of the corona pandemic and pray for the groom and the bride for success and blessing. They are honored to announce the wedding of their children

name of the bride

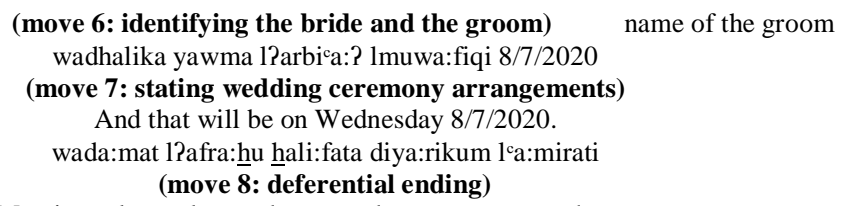

name of the groom

Figure 2. English translation and transliteration of the above wedding card

\section{Move 1: Heading}

This move occurs in only $18 \%$ of the data and it appears either before or instead of the 'opening' move in the current sample. The function of the 'heading' move is to identify the name of the genre. This move appears in Al-Ali's (2006) study, but it performs another different function, which is to identify the names of the groom and bride's tribes. In this study, the 'heading' move gives the genre name, which can help understand what the text is about. It is realized using a nominal sentence in which the subject and the predicate are nouns or pronouns, as seen in the following example:

\section{Pishha:ru zawa:jin.}

$$
\text { 'اشهار زواج' }
$$

\section{Announcing marriage.}

The subject (mubtad?) of this nominal sentence is absent (may be considered here hadha: : this) and the predicate (khabar) is Pishha:ru (announcing). Zawa:jin: (marriage) is an annex. The function of the predicate in Arabic is to give information that completes the meaning of the whole sentence. In this example, the predicate informs the readers that the sentence is about an announcement. Therefore, this heading may indicate that the text in question aims to announce the marriage and that request of people's attendance is not included. A reader would expect that the heading of an 
invitation card includes something about an invitation, such as dacwatu zafa:fin: (wedding invitation). Swales (1990) and Johns (1997) assert that the name of genre can identify the text and its purpose. Therefore, it can be said that the genre dealt with in the current study is wedding/marriage announcement cards (see move 5 for further discussion on the purpose of this genre).

Move 2: Opening

This move occurs in $73 \%$ of the invitations and it introduces the genre with Qur'anic verses, prophetic invocations and poetic verses aiming at promoting marriage. Almost all of the openings are either Qur'anic verses or prophetic invocations, while poetic verses appear in few openings. Openings with Qur'anic verses or prophetic invocations may reflect the couple's desire to have a blessed marriage and show the inviters' Islamic beliefs. For Muslims, starting an event with a Qur'anic verse is believed to be a blessing for that event. The Qur'anic verse that most inviters use is:

(ومن آياته أن خلق لكم من أنفسكم أزو اجا لتسكنو ا إليها وجعل بينكم مودة ورحمة إن في ذللك لآيات لقوم يتفكرون)

2- And among His Signs is this, that He created for you mates from among yourselves, that ye may dwell in tranquility with them. And He has put love and mercy between your (hearts): verily in that are signs for those who reflect.

Prophetic invocations aim to ask God's blessing that overwhelms the couples. Such invocations are derived from Prophet's Mohammad Sayings in congratulating men's marriage. The invocation that is shared in all of the cards, where the 'opening' move appears, is:

3- May God grant blessings to them and bind them with harmony and goodness.

$$
\text { 'اللهم بارك لهما وبارك عليهما واجمع بينهما في خر' }
$$

The last variety used to realize the 'opening' move is poetic verses that would express the couple's feelings and emotions about marriage. An example of this is:

$$
\text { 'سبحان من جمع القلوب بفضله و على رحاب الود عمر دارها، }
$$

4- Praise be to God whose generosity joined the hearts and Who established homes full of fondness.

Move 3: Identifying the celebrating families

The function of this move is to present the names of the families celebrating the wedding. The couple's families play an important role in the wedding ceremonies as the groom's family meet the bride's family to request the bride's hand (see section III. A.). Therefore, presenting the families' names in the wedding cards can reveal that marriage does not only unite the groom and the bride, but also connect their families. This move has low occurrence frequency (23\%) suggesting that its occurrence is not mandatory to realize the invitation genre. The invitation cards use the noun ?fra: $\underline{h}$ (weddings) followed by the names of the tribes, to which the groom and bride belong, as seen in the example below.

5- ?fra: $\underline{h}$ a:l cbyda:t wa a:1 hada:d

$$
\text { أفراح ال عبيدات و ال حداد }
$$

5- Weddings of the tribes of Aal Obeidat and Aal Hadad.

Move 4: Identifying the inviters of the wedding

All of the invitation cards include this move which has the communicative function of giving the names of the inviters for the wedding ceremony. The inviters are usually the fathers of the groom and the bride's (Al-Ali, 2006; Sawalmeh, 2015). Sawalmeh added that the cards are issued by another male from the groom or the bride's family, if either of their fathers is dead. This is true in the present sample. However, it is found that the inviters in a few wedding cards are the groom and the bride themselves. In addition, it seems that the inviters' main role has been changed from inviting people to attend the wedding ceremony physically to just announcing the marriage and inviting guests for remote participation. Such changes occurring in move 4 are likely because there is no longer an invitation statement that requests people's attendance, which cancels the main communicative purpose of wedding invitations (for supporting evidence and examples, see move 5).

Move 5: Announcing marriage and requesting distant participation

This move occurs in all of the study sample and it replaces move 4, 'requesting the presence of the guests' in Sawalmeh's outline. The main communicative purpose of wedding invitation cards is to invite guests to celebrate the wedding in such places as halls, hotels and the groom's house. Al-Ali (2006) asserts that the move, 'requesting the honour of participants' is an important one in the invitation genre as it enables the inviters to kindly request the invitees' participation. Therefore, it can be said that this move is essential because it serves the main purpose of these cards. However, this move is not found to occur in the present sample, as people cannot invite others to public gatherings due to restrictions imposed by the Jordanian government during the Covid-19 pandemic. These restrictions prevent such gatherings to stop the virus spreading, to keep the people safe and healthy. Instead, the wedding cards analyzed in this study employ move 5, 'announcing marriage and requesting distant participation' which has the function of informing people of marriage and request their participation without attending at one particular place. The following is a typical example of this move:

$$
\text { 'بدعو انكم لمشار كتهما الفرحة من منازلكم و الدعاء للعروسين بالتوفيق بمناسبة زفافهما في ظل أزمة كورونا، }
$$

6. yad'uwa:nakum limusha:rakatihima: lfarhata min mana:zilikum waduca:?a lilcaru:sayn bitawfi:qi bimuna:sabati zafa:fihima: fi THili Pazmati ku:ru:na:.

6. They invite you to share the joy from your homes [distant participation] and pray for the groom and the bride for success [seeking invitation] on the occasion of their wedding [announcing marriage] in the light of corona 
pandemic [justifying distant participation]. (my italics).

The first step within this move, 'invitation for distant participation' requests the invitees' participation from homes. It employs simple present tense in a verbalized phrasal verb in an active form, such as yad'uwa:nakum limusha:rakatihima (invite you to participate), or yatasharafu:n bidacwatikum (are honored to invite you). Considering that Covid-19 has caused the Jordanian government to issue some safety rules, this step may indicate that the inviters adhere to the governmental policies, which ban people's close contact, as they invite people to stay at home. The lexical choice in many other cards show stronger reflection of the inviters' adherence to these policies, using the noun Pal?iltiza:m (abidance), as seen below:

7. yad'uwa:nakum lPiltiza:ma bimana:zilikum.

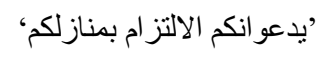

7. They invite you to abide in your homes.

Example 6 above reveals that the invitation for participation in the wedding includes asking the invitees to pray for the groom and bride. This realizes the second step within move 5, namely, 'seeking invitees' invocation'. This step can be a complement to step 1, as it shows how remote participation can be realized, considering that the invitees' prayer is part of their participation in the wedding. This step is realized by a coordinating conjunction $w a$ (and) and a conjoined noun walduca:? (invocation).

The third step, 'announcing marriage' has the function of informing people of the marriage. This is an important condition for realizing the marriage in Islam. In example 6 above, this step is realized using the prepositional phrase bimuna:sabati zafa:fihima: (on the occasion of their wedding). In some other cards, inviters use verbalized phrasal verb in an active form of an explicit statement to announce marriage, such as yuclina:n zafa:f(announce wedding). A typical example of this is:

8. yatasharafa:n bi?ishha:ri zawa:ji waladayhima:

$$
\text { ' يتشرفان بإنشهار زواج ولديهما، }
$$

8. They are honored to announce their children's marriage [announcing marriage]. (my italics)

The fourth step within move 5 is 'justifying distant participation'. Distant participation has been justified by the unusual circumstances caused by Covid-19, as seen at the end of example 6 above. This step is realized using the prepositional phrase fi THli ?zmati ku:runa (corona pandemic). This kind of justification may show that the inviters are keen to take their invitees' health into consideration.

The last step, 'identifying the channel of participation' presents the means of participation in the wedding. The way invitees can participate in wedding has been limited to mobiles and social media. This step is realized by simple present tense in passive form, as seen below:

$$
\text { 'تقبل التهاني و المبار كات على وسائل التو اصل الإجتماعي و الهو اتف فقط' }
$$

9. tuqbalu taha:ni: walmuba:raka:tu cala: wasa:Pili tawa:suli lPijtima:i: walhawa:tifi faqat.

9. Congratulations and blessings are accepted on social media and phones only [channel of participation]. (my italics)

6. Identifying the bride and the groom

This move introduces the names of the groom and bride in all of the invitation cards. As seen in figure 2 above, the groom's name is located on the right side while the bride's name is on the left. It was also noticed that some inviters add titles before the groom and/or the bride's names, which show their positions or academic degrees. However, in $27 \%$ of the data, only the groom's name is given, while the bride's name is substituted by honorific expressions like karymatuh (his honorable daughter) and Pami:ratuh (his princess). Such practice would reflect a traditional tendency by some people in keeping the name of women hidden. The use of the attached pronoun uh (his) in karymatuh may also indicate that a bride belongs to her male guardian even after marriage (Al-Ali, 2006).

Move7: Stating wedding ceremony arrangements

This move occurs in all of the invitations. It has the function of identifying the time of the wedding ceremony and reporting some ceremony arrangements. Sawalmeh reported that this move has four components: 1. timing and duration; 2. day of wedding; 3 . date of wedding; and 4. venue. None of these components, except for 'day and date of the wedding', has appeared in the present data. The day and date of a wedding are important for the purpose of announcing the marriage and people need to know when they can congratulate the groom and the bride. However, there is no need to inform the invitees of arrangements about the timing of wedding or its duration, as there is no place where people are invited to gather. This supports the absence of invitation from the data. The example below clarifies the steps of move 7 :

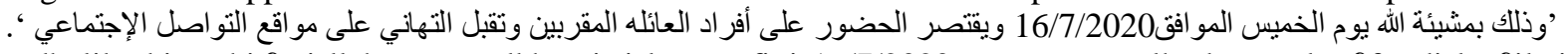

10. wadhalika bimashi:Pati llah yawma lkhami:si lmuwa:fiqi 16/7/2020 wayuqtasaru lhudu;ru cala: Pfra:di lca:Pilati wa tuqbalu taha:ni: cala: mawa:qici tawa:suli liijtima:ci:

10. And that will be with God's willing on Thursday 16/7/2020 [day and date of wedding]. Attendance is limited to close family members [ceremony arrangements]. Congratulations are accepted on social media sites. (my italics).

This example, like many other instances from the data, realizes the step 'day and date of the wedding' using the formulaic phrase bi-mashi:?ati-allah (if God permits) before the adverbs of time, without including any verb tense. The example replaces the usual mentioning of the 'venue' component by another step, namely, 'ceremony arrangements'. This new step mainly states that wedding ceremony is exclusive to family members and no party is taking place. It uses either simple present or future tenses (see example 11 below). The above example also shows that the 'venue' 
component, where close contact occurs, is replaced by the step, 'identifying channel of participation'. The occurrence of this step here shows that it forms part of the wedding arrangements, as it informs the invitees that they cannot physically attend and encourages them to use means of social media to achieve distant participation. It may be said here that inviters want to display their adherence to governmental policies by forbidding gatherings and close contact in the wedding ceremony.

In a few cards, there is an explicit statement which justifies such wedding ceremony arrangements by admitting that the inviters care about their invitees' health, as in the example below. The accusative of purpose maf'u:l li?ajlihi (hifaTHan) is used to give the reason of such arrangements:

$$
\text { 'سيقتصر حفل الزواج على أسرة العروسين في المنزل حفاظا على سلامة الجميع، }
$$

11. sayaqtasaru haflu zawa:ji cala: Pusrati lcaru:sayn hifaTHan cala: sala:mati ljami:ci.

11. The wedding ceremony will be limited to the groom and bride's family at home for everyone's safety [justifying arrangements]. (my italics)

Move 8: Deferential ending

The function of this move, according to Sawalmeh, is to close the invitation genre deferentially using either of the two components: 1 . wishing happiness to invitees 2. requesting the honor of their attendance. This latter component does not exist in the present sample, as invitation of presence is no longer involved. This move is realized in $75 \%$ of the present data by the step, 'making wishes and invocations', as seen in the following examples:

12. da:mat lRafra:hu hali:fata diya:rikum lca:mirati.

12. May joys always last and surround your prosperous homes.

, دامت الأفر اح حليفة دياركم العامرة؛

13. Pabcada llahu canna: wa cannakum lbala:?a wa lwaba:?a.

13. May God keep ordeal and epidemic away from all of us.

14. Pabcada llahu cannakum ku:ru:na: wa Pada:ma cafiyatakum.

14. May God keep Corona away from you and keep you well.

These Examples use simple past tense da:mat (lasted) and $\mathrm{Pb}^{c} a d a$ (keep away), but they report actions that have not finished yet. The use of these verbs in this context has a rhetorical function of continuing and renewing, so that the actions have the status of simple present tense. Examples 13 and 14 represent the inviters' invocations for invitees, as a new type of closing, which does not appear in Sawalmeh's data. A similar closing to this appears in Al-Ali's (2006) study, wherein the inviters call upon God to bless the groom and bride. However, in this study, the invocation reflects the effect of Covid-19 on this move, as the inviters pray for the invitees to be safe and in good health.

Move 9: Notification

This move shows another evidence of changes affecting the invitation genre that would cause disappearance of the invitation mode. There are six components of this move, according to Sawalmeh, which do not occur in the current study sample except for the last one. These are: 1. notices about supplementary parties; 2. requesting not to bring children to the wedding ceremony; 3. timing of taking the bride from her house to the groom's; 4. requesting the invitees not to fire bullets; 5 . requesting not to bring camera phones or cameras; and 6. name of the publishing company of the cards. Most of these components emerge as a response to the events that usually accompany the wedding ceremony, such as the men's evening party, the bride leaving her home with an escort and shooting bullets in the air. The declining of these events indicates that wedding celebrations are not taking place and therefore no invitation is included. The only shared step that appears in the wedding cards is the "name of the publishing company/designer of the cards'. This step appears in only $10 \%$ of the wedding cards by mentioning the name of the publishing company or the designer at the bottom of the cards.

\section{A. Moves Sequence}

The moves realizing most of the invitation cards appear in the sequence presented in table (1). However, the varied location that move 5, 'announcing marriage and requesting distant participation' occupies causes irregularities in this sequence. It occurs in a few cards after move 7, 'stating wedding ceremony arrangements' or just before it in some other cards. This can be due to the similarity of function between 'requesting distant participation' and 'wedding ceremony arrangements'. It can be said that the inviters' request of remote participation is part of the wedding arrangements, as can be seen in example 10 under move 7. In this example, the inviters accept congratulations remotely on social media instead of gathering in a 'venue' which is a cancelled component of the 'wedding ceremony arrangements'. This shows why the channel of participation, which is part of move 5 as mentioned above, occurs also immediately after move 7 .

The step 'seeking invitees' invocation' from move 5 also occupies another position which is before or after move 7 . Moreover, it is found that this step is repeated after move 7, as seen in the examples below:

$$
\text { 'يدعو انكم الالتز ام بمناز لكم و الدعاء لولديهما بالتوفيق و السعادة و البركة، }
$$

1. yad'uwa:nakum lPiltiza:ma bimana:zilikum waduca:?a liwaladayhima: bitawfi:qi wasaca:dati walbarakati.

1. They invite you to abide in your homes and pray for their children for success, happiness and blessing.

$$
\text { 'وذلك بمشيئة الله يوم الخميس '...' يكفي دعائكم لنا بالتوفيق و السعاده' }
$$


2. wadhalika bimashi:Pati llah yawma lkhami:si '...' yakfi: duca?akum lana: bitawfi:qi wasaca:dati.

2. And that will be with God's willing on Thursday '...' Your prayers of success and happiness satisfy us.

The first mention of invocation in example 1 is part of 'distant participation', which the inviters request. In example 2, the inviters seek again the invitees' invocation. However, it seems that the repetition here has a function, not a mere repetition of words. The inviters have not reported the place of the wedding in example 2 . The text indicates that the inviters do not want the invitees to attend the ceremony due to the Covid-19 pandemic, but they probably still want to maintain warm relationship with the invitees by seeking their invocation in compensation for their attendance.

\section{B. Non-linguistic Features}

Wedding invitation cards include some features that are not related to language and can easily distinguish them from other genres. The non-linguistic features that appear in Jordanian wedding cards are, as summarized by Sawalmeh (2015): colours, typography and images. Sawalmeh reported that his data include red, green, white and a combination of both white and black, as the most popular colours. About half of the cards he investigated, were a mix of white and black, as cards with these colours would be more affordable than other coloured cards. In the present study, it appears that the cards are highly decorated with many different colours. This can be due to the fact that the cards are electronic, so that the inviters, specifically with low budget, do not need to pay a lot for printing coloured cards.

As for typographical features, the cards in the present study are similar to those in Sawalmeh's study in that they employ typefaces that are visible and eye-catching for readers. In addition, the moves, 'opening', 'identifying the bride and the groom', 'identifying the inviters of the wedding', as reported by Sawalmeh, are printed in boldface with large size font. Although this is not the case in all wedding cards in the present study, the move, 'identifying the bride and the groom' in some cards is typed with a colour different from the one used for other moves.

The last non-linguistic feature is the insertion of attractive images that would represent and serve wedding ceremonies. Therefore, these images, among the non-verbal components, play a significant role in identifying the communicative purpose of the wedding genre. Examples of images that appear in the current study, are hearts, flowers, bunch of roses, wedding rings and a couple. What makes the present wedding cards different from those investigated in previous studies is the inclusion of an image that would represent coronavirus, or an image of a couple wearing masks, or both of them, as seen in the examples below. The first image represents coronavirus in green and the second shows a couple wearing mask.

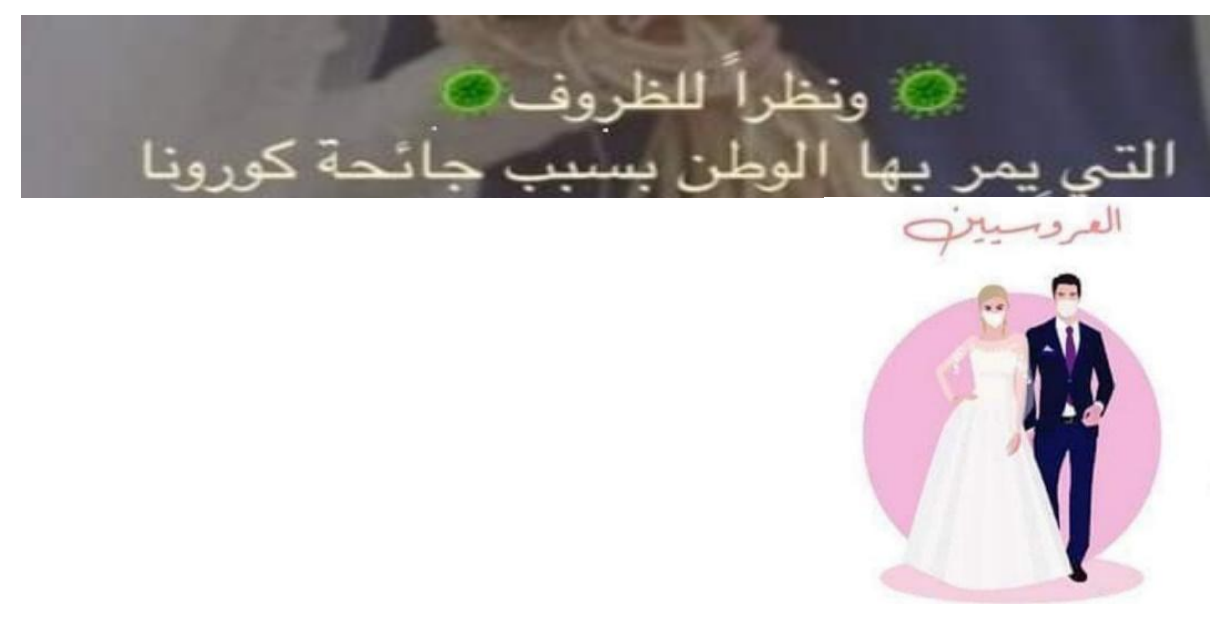

\section{CONCLUSION}

This study examines the rhetorical structure of Jordanian Arabic wedding invitation cards issued during the Covid-19 pandemic. It compares these cards with the ones analyzed by Sawalmeh (2015) to find out the effect of this pandemic on the wedding invitation genre. The findings reveal that there are some similarities between the moves and steps of the present data and the components found in Sawalmeh's. The shared moves are 'opening', 'identifying the celebrating families', 'identifying the inviters of the wedding', 'identifying the bride and the groom', 'stating wedding ceremony arrangements', 'deferential ending' and 'notification'. The similarity in occurrence of these moves would indicate the inviters' common practice for realizing wedding invitations.

The analysis also reveals that the present data includes some new moves and steps that do not appear in previous literature, as shown in table 1 in section V. Some previous studies, such as Al-Ali (2006) and Sawalmeh (2015), revealed that the wedding genre includes an important move whose purpose is to kindly request the attendance of invitees to gather in a specific place. The importance of this move emerges from the fact that it matches with the whole communicative purpose of the wedding genre, viz. to invite some people to celebrate the wedding in a specific place. This move does not appear in the present sample. Instead, the move, 'announcing marriage and requesting distant participation' appears to be the core of the present wedding genre. The occurrence of this move, with its constituent 
steps, in addition to the 'heading' move forms a strong evidence of the influence of the Covid-19 pandemic, showing that there is a noticeable change in the communicative purpose of the wedding genre tackled in this study. The change is also observed in the form of this genre in terms of the non-linguistic features. Including an image of a couple wearing masks may be considered a representation for the social practices in Jordan during the pandemic. The Covid-19 pandemic has forced the Jordanian government to impose certain rules which affect social practices, including wedding ceremonies. The changes in how these ceremonies run have been reflected in the wedding invitation cards.

The analysis of the linguistic features in this study shows how a step is realized and may help readers understand the purpose of the text and its segments. The analysis reveals that the dominant tense used in these wedding cards is the simple present. Simple past tense appears only in the closing move, but it still expresses actions in simple present tense. Such a feature of the present tense occurrence would indicate that the inviters want to inform people that marriage announcement is taking a place and a marriage is going to happen soon.

The status of the moves has also been examined by recording the occurrence frequency of each move. It was noticed that there are some moves which occur in all of the wedding invitations, namely: move 4 'identifying the inviters of the wedding', move 5 'announcing marriage and requesting distant participation', move 6 'identifying the bride and the groom' and move 7 'stating wedding ceremony arrangements'. There are also two other moves, 'opening' and 'deferential ending', which occur in $73 \%$ and $75 \%$ of the invitations respectively. The high occurrence frequency of these moves would indicate that they may be considered obligatory rhetorical features of the wedding invitations. On the other hand, the moves 'heading', 'identifying the celebrating families' and 'notification' may not be considered obligatory features needed to realize the invitation genre.

In the light of these study findings, the changes affecting the wedding genre would make it possible to name these cards as wedding announcement cards. The findings of this study would also inform those from other cultures about the changes in wedding ceremonies in Jordan and how people construct their wedding cards accordingly. Such findings may encourage researchers to conduct cross cultural studies to compare Jordanian wedding cards with other cards that have occurred in the same context.

\section{REFERENCES}

[1] Al-Ali, M. N. (2006). Religious affiliations and masculine power in Jordanian wedding invitation genre. Discourse \& Society, 17(6), 691-714.

[2] Bhatia, V. K. (2002). Applied genre analysis: a multi-perspective model. Ibérica: Revista de la Asociación Europea de Lenguas para Fines Específicos (AELFE), 4, 3-19.

[3] Bhatia, V. K. (2013). Analysing genre: Language use in professional settings (2nd edn.). London \& New York: Routledge.

[4] Bhatia, V. K. (2014). Integrating products, processes, purposes and participants in professional writing. In C. N. Candlin \& K. Hyland (eds.), Writing: Texts, processes and practices (2nd edn.). London \& New York: Routledge, 21-39.

[5] Biber, D. (1988). Variation across speech and writing. Cambridge: Cambridge University Press.

[6] Brett, P. (1994). A genre analysis of the results section of sociology articles. English for Specific Purposes, 13(1), 47-59.

[7] Bruce, I. (2008). Academic writing and genre: A systematic analysis. London \& New York: Continuum.

[8] Holmes, R. (1997). Genre analysis, and the social sciences: An investigation of the structure of research article discussion sections in three disciplines. English for Specific Purposes, 16(4), 321-337.

[9] Johns, A. M. (1997). Text, role and context: Developing academic literacies. Cambridge: Cambridge University Press.

[10] Kanoksilapatham, B. (2005). Rhetorical structure of biochemistry research articles. English for Specific Purposes, 24(3), 269292

[11] Kress, G. \& P. Knapp. (1992). Genre in a social theory of language. English in Education, 26(2), 4-15.

[12] Miller, C. R. (1984). Genre as social action. Quarterly Journal of Speech, 70, 151-167.

[13] Momani, K. \& D. Al-refaei. (2010). A socio-textual analysis of written wedding invitations in Jordanian society. LSP Journal, $1(1), 61-80$.

[14] Sawalmeh, M. H. (2015). Ceremonial Arabic writing: A genre-based investigation of wedding invitation cards and obituary announcements in Jordanian society. Ph.D. dissertation, University of Huddersfield.

[15] Sawalmeh, M. H. (2018). Jordanian wedding invitation as a genre: An analysis of rhetorical structure and linguistic features. International Journal of Linguistics, Literature \& Translation, 1(4), 106-114.

[16] Sharif, M. \& L. Yarmohammadi (2013). On the Persian wedding invitation genre. SAGE Open, 3(3), 1-9.

[17] Swales, J. M. (1981). Aspects of article introductions. Birmingham: University of Aston

[18] Swales, J. M. (1990). Genre analysis: English in academic and research settings. Cambridge: Cambridge University Press.

[19] Swales, J. M. (2004). Research genres: Explorations and applications. Cambridge: Cambridge University Press.

[20] Swales, J. M. \& H. Najjar (1987). The writing of research article introductions. Written Communication, 4(2), 175-191.

[21] Tawalbeh, A. (2019a). A proposed theoretical framework for the analysis of research articles. International Journal of Linguistics, 11(5), 286-297.

[22] Tawalbeh, A. (2019b). The rhetoric of accounts of methodology in English and Arabic educational research articles: A contrastive genre analysis. Ph.D. dissertation, University of Huddersfield. 
Ahmad I. Tawalbeh was born in Irbid, Jordan in 1979. He received his $\mathrm{PhD}$ degree in Linguistics form University of Huddersfield, UK in 2019. His research interests include Genre Analysis, Conversation Analysis, Discourse Analysis, and Pragmatics. He is currently an Assistant Professor in the Department of English Language and Literature, Irbid National University, Irbid, Jordan. He was a Lecturer at University of Hail and King Saud University, Saudi Arabia. 